This item was submitted to Loughborough's Institutional Repository (https://dspace.lboro.ac.uk/) by the author and is made available under the following Creative Commons Licence conditions.

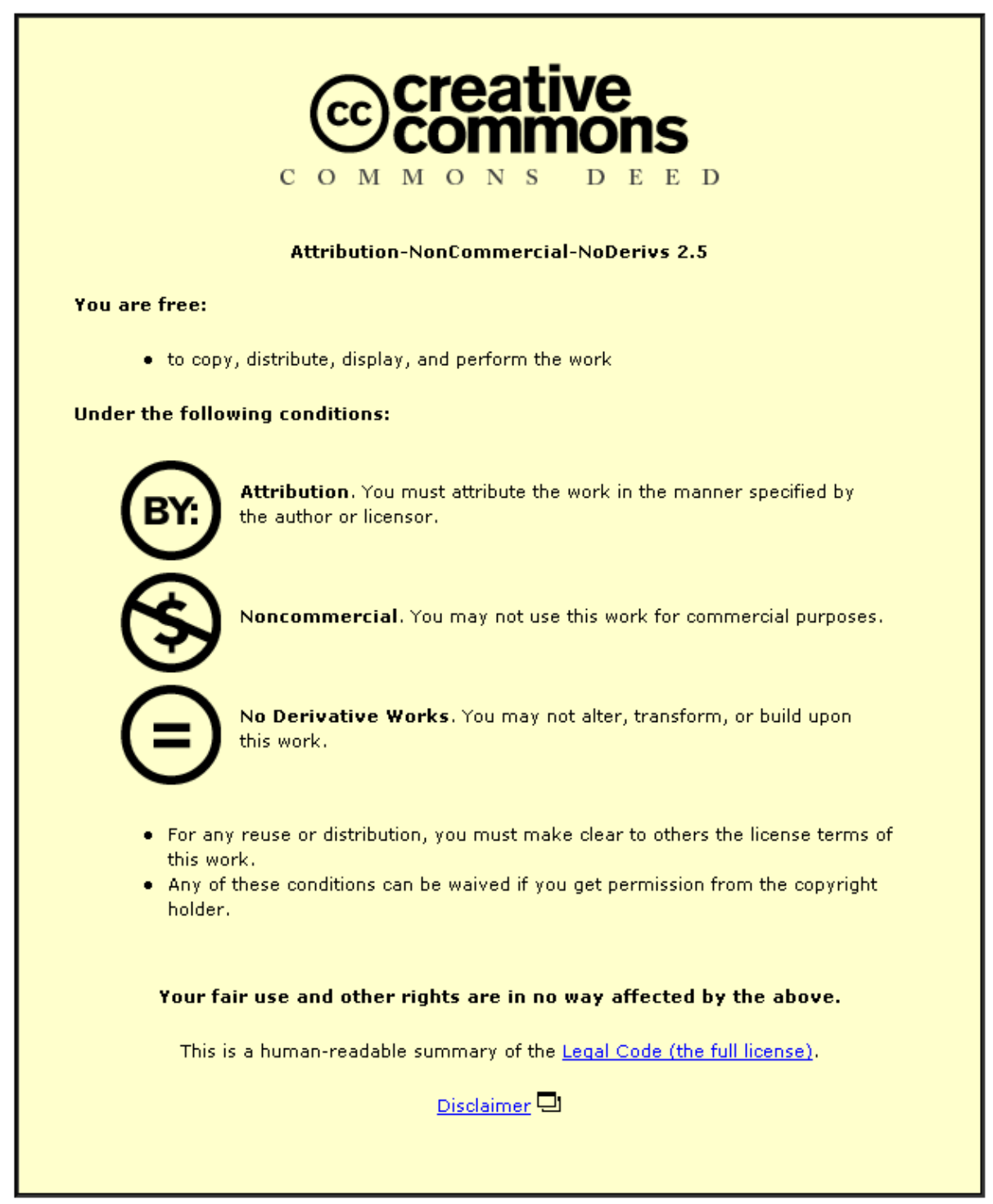

For the full text of this licence, please go to: http://creativecommons.org/licenses/by-nc-nd/2.5/ 


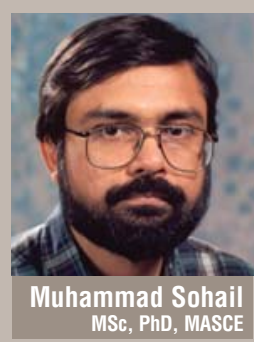

is a senior research manager at Loughborough University's Water, Engineering and Development Centre

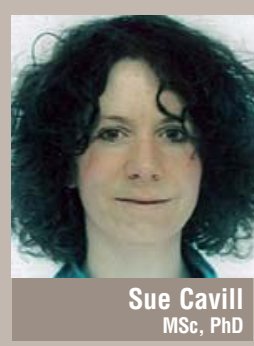

is a research scholar at Loughborough University's Water, Engineering and Development Centre

\title{
Ethics: making it the heart of water supply
}

\author{
Water ethics is an important but frequently ignored aspect of \\ water resource planning and infrastructure management. This \\ paper sets out seven basic concerns for the water sector in \\ developed and developing countries. These concerns are the \\ water cycle, quality of life, equity, sustainability, human rights, \\ externalities and governance. They are then used to develop \\ ten ethical principals that should be taken into account by water \\ professionals and decision makers if they are to achieve effective, \\ efficient and ethically acceptable water resource management. \\ Points for discussion are also raised on how ethics can play a \\ more prominent role in ensuring water provision for all.
}

The use of freshwater resources presents numerous problems that require ethical solutions if greater social equity and justice are to be achieved. Examples include competition for water between agricultural, domestic and industrial users, and the ecosystem becoming more fragile. Worldwide, more than 1 billion people still do not have access to safe drinking water (Fig. 1) and 3 billion people are deprived of basic sanitation services (Fig. 2). This paper sets out to answer the following questions: why should we be concerned with water ethics and what is the pragmatic relationship between ethics and water resource management and supply?

Ethics is the formulation and adherence to a set of values or beliefs. The term ethics refers not to morality itself but is the study of practical problems. It is a study of what we ought to do (actions and decisions) when faced with moral dilemmas and how we do it, both as part of an organisation and as individuals. Practicing water ethics often requires a change in people's behaviour and attitude towards water. This can be encouraged primarily through education and awareness of the value of water.

\section{Ethical principles related to water}

The World Commission on the Ethics of Scientific Knowledge and Technology created a sub-commission on the ethics of fresh water in order to develop common ethical principles related to water. These ethical principles are universally applicable for all countries at all stages of economic development. ${ }^{1}$

Human dignity - there is no life without water and those to whom it is denied are denied life.

- Participation-all individuals, especially the poor and women, must be involved in water planning and management.

- Solidarity - water continually confronts humans with their upstream and downstream interdependency.

- Human equity — rendering to all persons their due.

Common good - water is a common good and, without proper water management, human potential and dignity are diminished for all and denied to some.

- Stewardship —an ethical balance between 

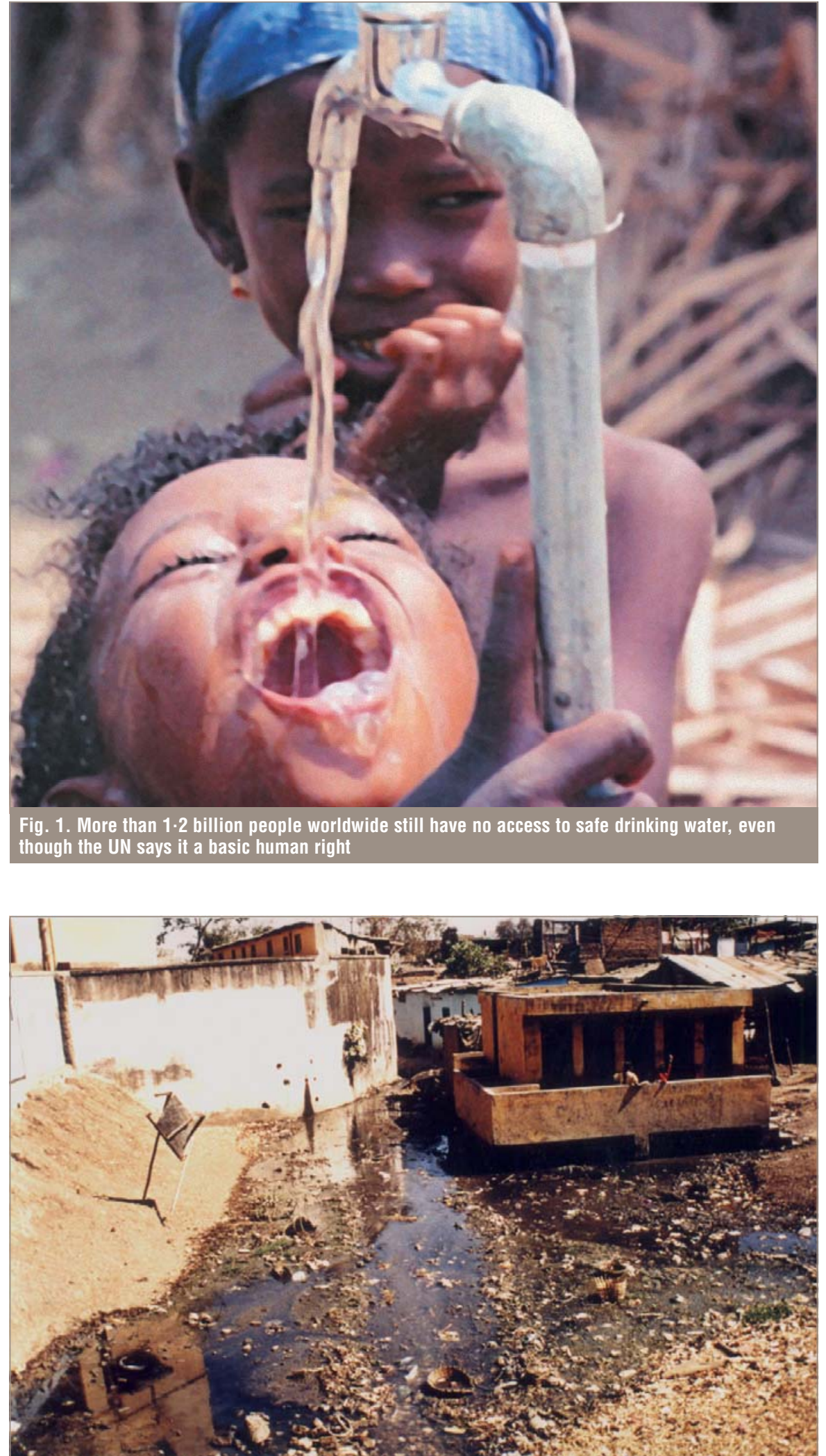

Fig. 2. Over 3 billion people are deprived of basic sanitation, which is directly linked to poverty and poor health using, changing and preserving water resources and land.

Traditionally, engineering professionals and technicians are accustomed to dealing with the technologies and hardware of water supply, but are not necessarily prepared to consider ethical issues. $^{2-4}$ This paper is intended as a starting point for water professionals, leading to the greater consideration of ethics in planning their future activities or policies. It will help them direct their efforts towards sustainable water resources management and to achieving a consensus on appropriate ethical responses and behaviours.

\section{Basic dilemmas for water supply}

Water resource management approaches are facing various ethical dilemmas ${ }^{5,6}$
water cycle
quality of life
- equity
- sustainability
human rights
- externalities
governance.

These dilemmas relate to water resource management in both developed and developing countries.

\section{Water cycle}

The water cycle is a useful starting point for describing how ethics and water supply interact. People's impact on the water cycle and natural resources, for better or worse, has a bearing on sustainability, equity and rights. In many parts of the world, the availability of freshwater resources are declining, the causes of which include

- population growth or migration, and accompanying domestic, industrial, municipal and agricultural needs

- deforestation

nollution of freshwater sources

- inefficient use of water-especially by irrigation systems

- lack of public awareness and education about water conservation

- climate change

- environmentally destructive developmentsuch as building dams, diverting rivers, building on floodplains.

International conferences and summits recognise the need to provide water for ecosystems. Agenda 21 and the World Summit on Sustainable Development both call for priority to be given to the satisfaction of basic human needs and to balance the requirement of preserving or restoring ecosystems. ${ }^{7,8}$ 
The ethical question that arises in this context is how to achieve a balance between the amount of water utilised in households, agriculture and industry and that which should be used indirectly to maintain ecosystems and conserve biodiversity for future generations. Similarly, international relations must also consider equity and fairness when it comes to sharing resources more fairly between people and countries, for example by developing water-sharing terms and treaties.

\section{Quality of life}

Inadequate quantity or quality of water has a high cost to households and governments-in the form of direct medical expenses, lost work time, lost education, lost economic productivity of sick workers and even death-and contributes to poverty. Improving the quality and quantity of water supply can therefore improve quality of life in a number of ways: for example it increases public health, welfare, security, comfort, convenience, income redistribution and poverty reduction, as well as enhances human capital. An adequate water supply might also improve a household's ability to generate income and savings, for example, by enabling a more productive use of women's time or enhancing the scope of household-based businesses.

The adequate provision of water also has wider implications for economic growth in terms of the efficiency of economic activities, facilitating trade and creating employment, which also have consequences for the quality of life. However, if quality of life is to be significantly improved, attention and resources should also be given to sanitation and hygiene.

\section{Equity}

Equity in the availability and use of water is an important ethical issue and refers to concepts of fairness and justice. Water has been recognised as a finite resource and an economic commodity with an economic value in many international declarations (such as the International Conference on Water and Environment, Dublin 1992; the Second World Water Forum, The Hague 2000; the International Conference on Freshwater, Bonn 2001; and the World Summit on Sustainable Development, Johannesburg, 2002) and the policies of major lenders and donors (for example in the EU Water Framework Directive).

A concern for equity in discussions of cost recovery and financial sustainability raises the issue of affordability of water as an element in an ethical approach to water and sanitation. The Ministerial Declaration of the Second World Water Forum states that the waterpricing approach, particularly in developing countries, should take account of the need for equity and the basic needs of the poor and the vulnerable. ${ }^{9,10}$ Practical questions must also be asked such as should water supply be cut off from those who are unable to pay?

Lack of access to adequate supplies of water for drinking, sanitation and irrigation is directly related to poverty and poor health. More than 1.2 billion people do not have access to safe drinking water, 3 billion people are deprived of basic sanitation services and more than 800 million people do not have enough food to meet their basic nutritional needs. The UN Millennium Declaration calls for reducing by half the proportion of people without sustainable access to safe drinking water and extreme poverty by the year $2015 .{ }^{11,12}$

It is the poor who are most commonly denied their basic rights to water supply. The poor also have less of the social, political and economic resources necessary for achieving an adequate supply. This means that in many developing countries the very poor often have to buy their water from vendors at a price that is 10-20 times higher than water sold through the distribution network. In many rural communities women and children spend several hours each day collecting water from distant sources (Fig. 3).

\section{Sustainability}

The Brundtland Report defined the principles of sustainable development as 'meeting the needs of the present without compromising the ability of future generations to meet their needs'. ${ }^{13}$ With reference to water supply, the literature finds that drinking water supplies are sustainable if ${ }^{14}$ the water consumed is not overexploited but naturally replenished

- facilities are maintained in a condition that ensures a reliable and adequate potable water supply

a the benefits of the supply continue to be realised over a prolonged period of time.

Sustainability in the context of water management depends on both the sustainability of improvements to the environment and conservation of the natural resource as well as the sustainability of the operation and maintenance of infrastructure.

\section{Human rights}

Rights are defined as privileges established under an explicit or an implicit criterion, with or without direct or indirect payments, accruing to an individual or a group. Access to water and sanitation are basic human rights.

In 2002, the UN recognised water as a human right through a formal comment by the UN Committee on Economic, Social and Cultural Rights: 'The human right to water entitles everyone to sufficient, safe, acceptable, physically accessible and affordable water for personal and domestic uses'. It further recognises that state parties 'have an obligation to progressively extend safe sanitation services'.

Food security is another basic human right and water for agriculture is one of the driving forces of poverty alleviation and economic sustainability of a country. By incorporating rights to water into national laws and policies, nation-

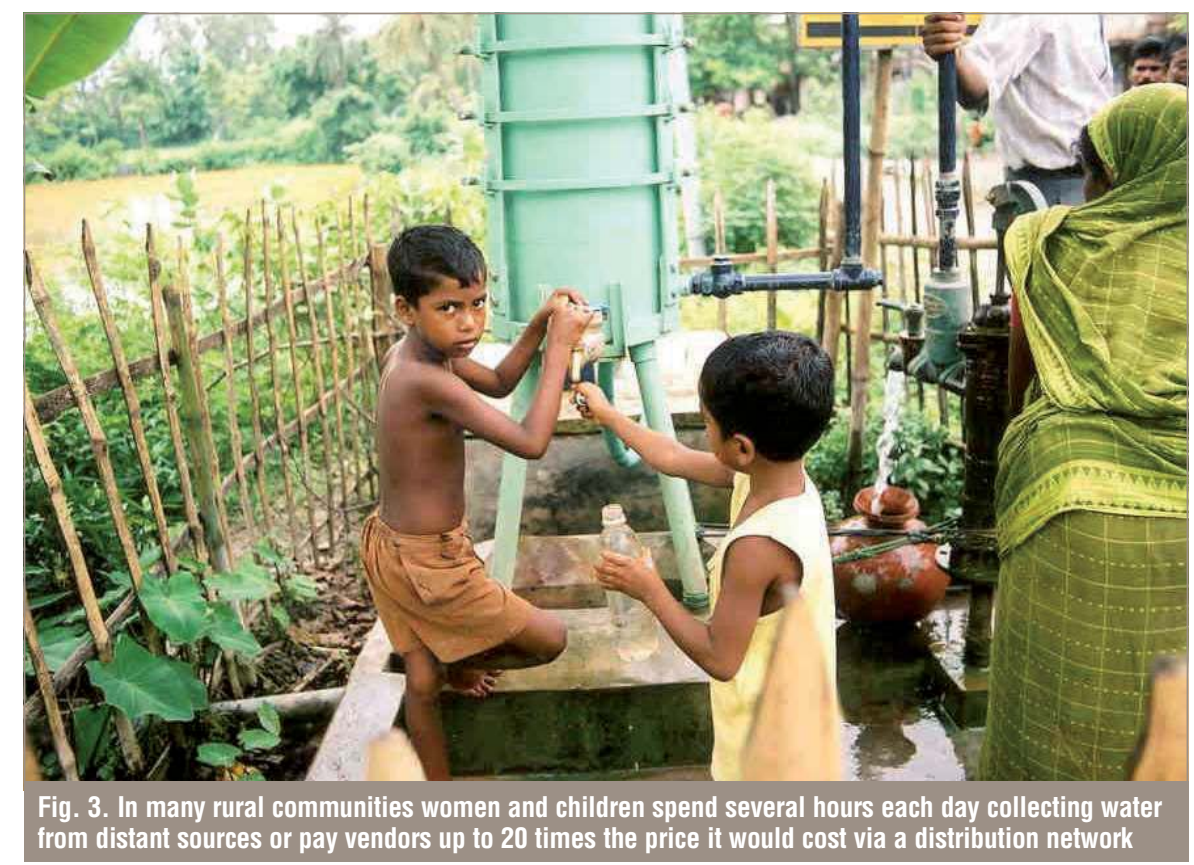


al governments are accountable to electorates for progressively realising access to adequate water supplies.

However, this right to water needs further clarification. For example, how much water, and of what quality, do individuals have a right to? The level of basic water requirement suggested by the World Bank, the World Health Organisation, the US Agency for International Development and the UN range from 20-50 1/day. What responsibilities do individuals have in relation to this right? What kind of access is necessary to fulfill this right, for example wells or piped household water supply? What priority does the individual's right to water have in relation to other uses (for agricultural industry, leisure, the environment)? How is the realisation of this right to be monitored?

\section{Externalites}

Water for domestic purposes represents a very small portion of the total water consumed. The majority of water is allocated to agricultural uses, such as irrigation, or industrial uses, such as the production of electrical energy, mining, oil and gas. Meeting these demands can often have environmental consequences such as the pollution of surface and groundwater supplies by agricultural and industrial chemicals, for example arsenic, nitrates, cyanide, mercury, lead, polychlorinated biphenyls and pesticides. Other externalities that threaten water quality include increasing population and migration into cities, the costs of water treatment and decontamination, over-pumping of aquifers near coasts, or high sedimentation of rivers due to massive deforestation.

Furthermore, the impacts of industry on climate change and the consequences for water supply and distribution should be understood and mitigated. The externalities involved in the use of water are an environmental but also a political problem (who pays the cost and who benefits). For example, who should pay the costs when resources, including water, are used for economic development that only benefit a minority or when rural populations suffer from urban water pollution and industrial development?

\section{Governance}

A new water ethic would seek to ensure good governance, participation and more transparent decision making in water resource management. Better water governance is intended to promote more sustainable development, civil harmony and social integration.

The Bonn Recommendation and South Asian Water Vision 2025 recognise that water governance should improve accountability, introduce and enforce appropriate legal provisions against corruption, monitor the performance of public institutions and private companies, develop codes of conduct, and invite civil society to play an active role in these processes. ${ }^{15,16}$

Similarly, Agenda 21 promotes the principle of subsidiarity and encourages all parties affected by water management decisions to participate in the design, planning, provision and monitoring of water and sanitation services. In particular, greater openness and transparency are fundamental requirements when public responsibility for water supply is shifted to private entities.

\section{Ten principles of water ethics}

Based on the above discussion, ten principles of water ethics are suggested below. These are intended for use by national and local water managers and planners, policymakers, and the public to achieve effective, efficient and ethically acceptable water resource management.

Priority in water management should be given to thirsty humans.

- Allocate indisputable water rights to all people.

- Treat water sources as a common resource.

- Use water resources in a way that protects the rights and advantages of future generations.

- Develop sustainable distribution and treatment facilities for water supply.

- Respect and protect the watershed, surface water body or groundwater aquifer (and its recharge area).

- Be mindful of water quality, for example by disposing of pollutants properly and developing new strategies to prevent contamination.

- Be mindful of the quantity of water used for domestic, industrial, municipal and agricultural needs.

Exercise the principle of equity in the distribution of water.

- Treat the public health aspects of water provision as minimum standards.

\section{Some points for discussion}

As described, the use of water resources presents numerous ethical concerns, whose solution requires ethical reflection. Further points for discussion include the following.

\section{Do lakes, rivers, oceans, aquifers have an} intrinsic value outside of human use?

Public policy must ensure the sustainability of safe water supplies for the benefit of all people and the natural environment. For instance, philosophers may defend the view that rivers and other water bodies have a value independent of the instrumental value they may have for humans or other sentient creatures.
Is the market a reasonable concept to deal with water?

It is important to recognise that water is a public resource, not a commodity. For example developing countries are under pressure in the World Trade Organisation's general agreement on trade and services negotiations to 'progressively liberalise' their water sectors to foreign corporations. It is important to ensure that privatisation of water supply and sanitation has sufficient public oversight and access and the ability to reverse commitments before undertaking privatisation of the water sector.

What is the ethical responsibility of developed countries to developing countries?

Increasing water and sanitation coverage has a key role to play in terms of supporting the UN Millennium Development Goals, poverty reduction, and growth, but its importance is not reflected in either development assistance or domestic public funding to the sector. Greater commitment should be made to meet the basic water and sanitation needs of the poor. For example, northern governments and international finance institutions should provide more official aid to the water sector and governments in developing countries should increase their financial allocations to the water sector and ensure that resources will be addressed to the poor and not wasted.

What responsibility do we have to future generations for water quantity and quality?

The fact that members of future generations do not exist yet should not be a reason for giving less consideration to their interests than we give to our own.

How can a balance be struck in water pricing to ensure financial sustainability while recognising poverty?

If the UN Millennium Development Goals are to be achieved, the water and sanitation sector has to take into account social and economic inequity. The basic principle should be that, where the poor cannot afford to pay the full cost of water supply, tariff systems should enable social targeting.

Water should not be denied to households that cannot pay. Options for considering poverty in water pricing include subsidy arrangements from public funds, cross-subsidisation from wealthier to poorer users or from commercial to domestic users. The main goal of the sector should be to maximise the use of resources to allow disadvantaged people access to sustained water and sanitation services.

Should the availability of water be considered a human right?

Binding and enforceable rights of access to water under national laws are a step towards fill- 
ing the gaps in adequate and safe water supply, yet only South Africa has made access to water an explicit right in its constitution and corresponding implementing legislation.

The legal allocation of water rights should be reviewed to address inequities, environmental justice concerns, and inefficient use of water. Ethically, the world's water resources should be managed to ensure that each person is allotted a basic entitlement of drinking water, in order to guarantee a minimum quality of life below which no one would be allowed to fall.

How can we build effective water institutions and alliances between non-government organisations, communities, local governments and environmental organisations?

In recent years coalitions of civil society organisations have started to campaign for adequate and safe water supply and sanitation services for all, based on rights, popular participation and mechanisms of social control to ensure transparency and accountability in service delivery. In response, internationally, the water sector is beginning to realise that it needs to listen to and respect what water users say.

How can we protect water resources (for example against the possible effects of global climate change)?

Desertification, land degradation caused by human-induced factors and climate change will affect water resource management and supply. Such environmental conditions have implications for agriculture, human health, coastal ecosystems, forests and so forth. The management of water resource systems should allow for the possible effects of environmental change. For example, while climate change is expected, the extent of future greenhouse gas emissions depends upon the decisions of governments and individuals, the use of alternative energy systems, population sizes and other factors.

\section{How can strategies to manage demand be implemented?}

Recently, a number of demand-management options have been developed, such as improving efficiency, conservation, modifying demand, altering water-use processes, pricing mechanisms, consumer education and changing land-use patterns in floodplains.

The Dublin conference stated that since water sustains all life, water resources should be effectively managed through a holistic approach, linking social and economic development with protection of natural ecosystem and to preserve threatened or endangered species. ${ }^{17}$

\section{Conclusions}

This paper raises a number of issues in relation to water ethics with reference to the fol- lowing questions: why should we be concerned with water ethics and what is the pragmatic relationship between ethics and service provision?

In response to the first question, the main benefit of applying ethics to water resources management and supply is in promoting systems based on justice, equity and equitable access to public resources. For example, ethical service delivery at global and national levels would involve

meeting national and international legal obligations and responsibilities to ensure that people receive their basic water requirements

- improving the quality of life of poor people

- facilitating more grassroots participation in water resource management and planning, especially that of the poor and vulnerable

resolving international water disputes and conflicts over the use of shared water

- creating a greater understanding of the different impacts of privatisation of water supply and sanitation on the rural and urban poor ensuring that water sectors are transparent and accountable bodies

- ensuring the allocation of sufficient resources for water management.

Secondly, the relationship between ethics and water resource management and water supply is a practical response to current problems of effectiveness, efficiency and sustainability in resource management and service delivery.

The relationship between ethics and water resource management and water supply has been explored in this paper with reference to seven basic concerns - the water cycle, quality of life, equity, sustainability, human rights, externalities, and governance - and ten principles of water ethics have been suggested for the water professional.

It is time that all stakeholders in water resource management and supply_hydrologists, civil engineers, water planners, water managers, policy makers, citizens, cross-sectoral alliances, civil society organisations and governments among others-re-evaluated their fundamental beliefs concerning water and act together to achieve ethical provision of water for all.

References

I. LORD SELBORNE. The Ethics of Freshwater Use: A Survey. UNESCO, Paris, 2000. Available at: http://www.unesdoc. unesco.org/images/0012/001220/122049e.pdf

2. OAKLEY H. R. and FARRELL K. Workshop meeting. Ethics and the Engineer. Proceedings of the Institution of Civil Engineers-Part I, 1988, 84, I313-1315.

3. STAINER L. and STAINER A. Management decision making an ethical perspective. Proceedings of the Institution of Civil Engineers-Municipal Engineer, 2003, 156, No. 4, 223-227.

4. FAN L. C. N. Decision making models for handling ethical dilemmas. Proceedings of the Institution of Civil Engineers—Municipal Engineer, 2003, 156, No. 4, 229-234.

5. HODGKINSON D. and SOHAlL M. Ethics—a key issue. Proceedings of the Institution of Civil Engineers-Municipal Engineer, 2003, 156, No. 4, 217-219.

6. RAHAMAN M. M. and VARIS O. The Ethics of Water: Some Realities and Future Challenges. Available at: http://www. water.hut.fi/pdl/Rahaman2003_p3.pdf

7. ANON. EU Water Initiative for WSSD. Water for Life, 2002. Available at: http://www.inbonews.org/divers/thonon/ presentations/Thonon.PDF

8. UNITED NATIONs. World Summit on Sustainable Development, Johannesburg, 2002. Report A/Conf.199/20. Available at: http://www.johannesburgsummit.org/html/documents/summit_docs/131302_wssd_report_reissued.pdf

9. ANON. Second World Water Forum and Ministerial Conference, The Hague, 2000. Available at: http://www. worldwaterforum.net/

10. ANON. Ministerial Declaration. Second World Water Forum and Ministerial Conference, The Hague, 2000. Available at: http://www.worldwaterforum.net/

II. United NATIONs. United Nations Millennium Declaration. United Nations, New York, 2000. A/RES/55/2. Available at: http://www.un.org/millennium/declaration/ares552e.pdf

12. UNITED NATIONS. Implementation of the Millennium Declaration: Fact sheet I \& 2. United Nations, New York, 2000. Available at: http://www.un.org/millenniumgoals/index.html

13. HARLEM G. Our Common Future. Report of the World Commission on Environment and Development (The Brundtland Report). Oxford University Press, Oxford, 1987.

14. DAVIS J. and BRIKKE F. B. Making Your Water Supply Work: Operation and Maintenance of Small Water Supply Systems. IRC, Geneva, 1995.

15. GWP-SASTAC. Water for 2Ist Century: Vision to Action-South Asia. SASTAC, India, 2000.

16. ANON. Ministerial Declaration. International Conference on Freshwater, Bonn, 200I. Available at: http://www.water200I.de/outcome/Ministerial_declaration.asp

17. WORLD METEOROLOGICAL ORGANISATION. International Conference on Water and Environment, Dublin, 1992. See http://www.wmo.ch/web/homs/documents/english/icwedece.html 